\title{
The Revival of Vertical Integration: Strategic Choice and Performance Influences
}

\author{
Dongli Zhang \\ Assistant Professor in Management Systems, Gabelli School of Business, Fordham University \\ 441 East Fordham Road, Hughes Hall 510, Bronx, NY 10458, USA \\ Tel: 718-817-4145 E-mail: dzhang@fordham.edu
}

Received: October 28, 2012

doi:10.5430/jms.v4n1p1
Accepted: November 15, $2012 \quad$ Online Published: February 15, 2013

URL: http://dx.doi.org/10.5430/jms.v4n1p1

\begin{abstract}
For the past few years, several big companies have taken actions to gain more control over their supply chains. Against the popular trend of outsourcing, they tend to go back to gain a higher level of vertical integration. Just as outsourcing once raised challenges to global management, the revival of vertical integration sure brings benefits as well as new challenges. Motivated by this recent phenomenon, this paper investigates the influences of strategic choices on the change of vertical integration level and the performance implication of such changes. The findings support the cost-driven concern of the decisions on vertical integration level changes and certain performance benefits that the changes would bring to the companies.
\end{abstract}

Keywords: Vertical integration, Outsourcing, Transaction cost

\section{Introduction}

It has been noticed that some big companies are taking a page from the past. Instead of outsourcing more functions, they are trying to gain a higher level of vertical integration. Oracle acquired Sun in 2010, and since that time Oracle has transformed into a maker of software, computers, and computer components - a company more like the highly vertically integrated companies of the 1960s than the detailed fragmented technology industry of recent years. This is especially surprising since it happens in the technology industry, where specialization and outsourcing have dominated for decades. Apple is another example of a highly vertically integrated organization in the information technology sector. The company owns the designs of its own computer hardware, accessories, operating system and much of its own software itself. In some other businesses such as oil industry, many multinational companies such as ExxonMobil, Shell and BP almost own the whole supply chain, which includes everything from the oil drilling, the transportation of crude oil, and the refining and distribution process to company-owned retail stations in the local communities.

Others moving of vertical integration recently (in the past five years) includes some big companies such as PepsiCo Inc., General Motors Co., and Boeing Co. Each of the companies has its own strategic reasons for moving toward this direction. The companies trend to gain more control of raw materials, distribution, or manufacturing across the supply chain. This trend and phenomenon of going back to vertical integration from outsourcing motivates this study on the strategic changes of vertical integration.

Vertical integration is usually viewed as the extent to which a firm controls the production of its inputs or supplies and the distribution of its outputs or finished products (Mpoyi, 2003; Fernandes and Tang, 2012). It involves a variety of decisions concerning whether corporations should provide certain goods or services in-house or purchase them from outside firms. Over the years, vertical integration is used to serve different strategic objectives. From the emergence of the modern industrial enterprise in the late 1880 s to the 1970 s, vertical integration has been an important portion of corporate strategy for a long time. Companies pursue high levels of vertical integration to control the source of supplies, to realize economies of scale and scope, and to reduce market transaction costs (Chandler, 1990; Williamson, 1985). A turning point in vertical integration decision occurred in the late 1970s. Some companies reduce their levels of vertical integration by performing vertical disintegration (Kaitie, 2003). Some other companies maintained the same levels, while a few others actually increased their levels of vertical integration (Mpoyi, 1997; Brickley et al., 2012). The emergence and boom of outsourcing in the recent two decades also 
challenge vertical integration decisions (Kouvelis, 2002). Literatures on vertical integration begin to have two different views. On the one hand, some scholars believe that vertical integration is still a booming phenomenon in many U.S. industries and companies can achieve high performance through it (McAfee, 1999). On the other hand, the usefulness of vertical integration has come under attack in some strategy literatures, and some researchers recommend that firms should disintegrate, de-vertically integrate, or outsource (Barreyre, 1988; Harrigan, 1985b; Quinn et al., 1990). The inconsistent views and practices of vertical integration make some scholars pay attention to the changes of vertical integration in both directions instead of recommending one-direction solutions. For example, Mpoyi and Bullington (2004) conduct a research to examine the impact of changes in vertical integration levels on costs. They find that changes in vertical integration levels lead to declining production costs. However, their research only establishes the relation between changes of vertical integration and one dimension of performance, which is cost. There are still many questions on the topic that need answers. This research is an attempt to address several critical questions in this field: what factors may influence changes of vertical integration level, will different business strategies equally impact them, do the firms get what they want from changing vertical integration levels, will the changing of vertical integration levels results in superior performance besides low cost? To address these issues, this paper will empirically examine the impact of different business strategies on the changing of vertical integration levels and the relationship between changes of vertical integration level and performance.

The rest of the paper is organized as follows. A brief literature review on vertical integration and its underlying theory are first described. A framework and hypotheses are then developed. Data from World-Class Manufacturing Research Round Two is used to test the hypotheses and the empirical results are discussed in the paper.

\section{Literature Review and Theoretical Background}

Being viewed as an important corporate decision, vertical integration has been investigated by many researchers. Based on Mpoyi (2003)'s definition, vertical integration is the extent to which a firm controls the production of its inputs or suppliers and the distribution of its outputs or finished products. According to whether it is between or within the stages of the value-added chain, vertical integration can be viewed as two kinds (Davis and Duhaime, 1992). Between-stage vertical integration occurs between stages such as raw material producing and manufacturing or manufacturing and distribution. Within stage vertical integration occurs within a single stage of the value-added chain. Most researches on vertical integration use another way to classify vertical integration, which results in backward integration into the supply of materials or components and forward integration into distribution and sales (e.g. John and Weitz, 1988; D’Avenei and Ravenscraft, 1994; Rindfleisch and Heide, 1997).

Economic theories have been widely used to explain vertical integration strategies. Among them, Transaction Cost Theory (TCT) is the most commonly used one (e.g. Anderson, 1985; John and Weitz, 1988; Steenkamp and Geyskens, 2012). Pioneered by Coase (1937) and developed principally by Williamson $(1975,1985)$, TCT has been used in several main contextual domains, such as vertical integration, vertical interorganizational relationships, and horizontal interorganizational relationships (Rindfleisch and Heide, 1997). TCT views the firm as a governance structure, and firms and markets are alternative governance structures that differ in their transaction costs. TCT posits that there are costs in using a market. Both Coase and Williamson examine factors affecting the organization of production systems in a market-hierarchy framework. In such a framework, the organizational criterion is minimization of production and transaction costs (Williamson 1979). According to TCT, when a company tries to determine whether to use the market or to produce goods or services on its own, market prices are not the only factor needs to consider. Rather, there are significant transaction costs, which include operations costs (e.g. search costs), contracting costs, and monitoring and coordination costs (Gurbaxani and Whang, 1991). Monteverde and Teece (1982) conduct the seminal study in the context of backward integration by applying TCT to examine the make-or-buy decision for assembly components of two firms in the U.S. automobile industry. After their work, the make-or-buy issue for production inputs has been examined by many scholars, such as Masten, Meehan, and Snyder (1989), Walker and Weber (1984), and Lieberman (1991). In terms of forward vertical integration, TCT studies focus on the integration by manufacturers into distribution in both domestic and international contexts. The locus of this paper is on the backward integration, so in the rest parts of the paper vertical integration is used to stand for backward vertical integration only.

Based on TCT, there is substantial theoretical justification in existing literatures for the benefits of implementing vertical integration. Through vertical integration, costs may be decreased by reducing transaction costs (Jones and Hill, 1988; Mahoney, 1992), by decreasing uncertainty or asymmetric information, resulting in a more efficient use of inputs (Riordan and Sappington, 1987), and by protecting proprietary technology (Jones and Hill, 1988). Williamson (1975) extensively considered the impact of vertical integration on transaction costs, which include the 
costs of finding, selling, negotiating, contracting, monitoring, and resolving disputes with other firms in open market transactions. He proposed three aspects through which vertical integration reduces transaction costs. First, with proper management of business-level managers, corporate managers can replace profit maximization at individual stages with joint profit maximization. Second, there exist a wide variety of control instruments under vertical integration. In particular, hierarchical control can be used to solve problems that might arise from market transactions. Third, vertical integration improves information exchange between successive stages of production.

However, the usefulness of vertical integration strategies has come under attack in the strategy literature recently. There is an increasing number of studies that talk about the disadvantages of vertical integration, especially in the literatures on outsourcing. With the help of new information technologies, transaction costs in using the open market have been dramatically decreased, and a growing trend toward vertical disintegration has appeared. Cost saving has been claimed by many researchers who promote outsourcing (e.g. Lei and Hitt, 1995; Quinn, 1992). Compared to outsourcing, vertical integration is said to raise costs for several reasons. Depending on internal ability may result in strategic inflexibilities that trap firms into keeping obsolescent technologies and strategies (Dess et al., 1995). Since vertical integration creates complex problems of control and coordination among highly interdependent activities, managerial inefficiencies may develop (D’Aveni and Ilinitch, 1992). Moreover, vertical integration may force firms to forgo purchasing at low prices in the open market (Quinn, et al., 1990).

The two different views share one thing in common: lack of generalizable empirical test. So although there exist plenty theoretical justifications and anecdotal evidences, the relationship between vertical integration and its performance outcomes are still unclear (Peyrefitte and Golden, 2004). Based on the two different views, several factors have been identified to determine whether buying from independent suppliers or vertically integrating is more efficient. These factors include the number of competitors, technological and demand uncertainty, and prior levels of vertical integration (see in Balakrishnan and Wernerfelt, 1986; Chandler, 1990; Harrigan 1984; Williamson, 1981). According to existing research, the factors that determine vertical integration have changed significantly in recent years. For example, the number of competitors has considerably increased, most industry's environments are now highly uncertain (Chandler, 1990; Stuckey and White, 1993). The change in these determining factors may have led to a significant change in vertical integration strategies. Mpoyi and Bullington (2004) argue that if firms make changes in vertical integration level, no matter which direction the change toward, it will lead to declining production costs. However, their research did not address whether firms with different strategic objectives equally change their vertical integration level, nor did they check the impact of vertical integration changes on other performance measures.

\section{Theoretical Development}

Noticing the inconsistent views on vertical integration and the incomplete research on changes of vertical integration, this paper attempts to address how different business strategies will impact the changes of vertical integration level and how the changes will influence performance. Business strategic objectives influence the changes of vertical integration level. Companies pursue low cost strategy may try to achieve their goal by adjusting their vertical integration levels. To the contrary, firms with differentiation strategy tend to keep certain levels of vertical integration to insure the required market flexibility. Changes of vertical integration levels, no matter which direction they toward, will influence performance. Figure 1 shows the proposed relationships between business strategy, changes of vertical integration level, and operating performance. The figure indicates a direct effect of business strategy on changes of vertical integration level and a direct effect of changes of vertical integration level on operating performance. These proposed relationships are explained below.

$<$ Insert Figure 1 Here $>$

\subsection{Business Strategy and Changes of Vertical Integration Level}

There are several factors that may affect the choice of vertical integration level, such as phase of industry development, business strategy, and volatility of competition (Harrigan, 1985b). Porter (1980) develops the idea that all business strategies involve a choice between differentiation and delivered cost. He offers two fundamental types of business strategies: cost leader and differentiation, which have been used extensively in manufacturing research. Cost leaders often pursue any possible ways through which the cost of providing a product can be lowered and the economies of scale can be reached. We would expect vertical integration to take place when cost reduction through integration is possible. We would expect the same for the changes of vertical integration levels. As Robins (1993) suggested, the choice between vertical integration and markets is driven primarily by cost-efficiency. If cost associated with external supply is high, vertical integration is an appropriate choice. If independent production is less costly, then using external market is more efficient. A company with cost leader strategy will track the possible 
changes of cost closely in order to achieve its strategy. When transaction costs associated with market-based transactions increase, a firm may increase its vertical integration level and obtain more from inside suppliers. On the contrary, when new technology or new transportation channels make transaction costs lower than internal governance costs, a firm may decrease its vertical integration level and obtain more from outsiders. Firms with differentiation strategy does not ignore costs, but rather pay attention to the quality and diversity of the products at a cost that targeted customers are willing to pay. So differentiators will not adjust their vertical integration levels as much as cost leaders just in order to get lower cost. The above argument leads to hypotheses 1 and 2 .

H1. Firms with cost leader strategy tend to change vertical integration level to fulfill their strategic objective.

H2. Firms with differentiation strategy tend to keep vertical integration level to fulfill their strategic objective.

\subsection{Changes of Vertical Integration and Operating Performance}

Previous research often treats operating performance as with four dimensions: cost, quality, delivery, and flexibility (e.g. Klassen and Whybark, 1999; Roth and Miller, 1990). Accordingly, this study also examines manufacturing performance with these four dimensions.

\section{Changes of vertical integration levels and cost performance}

Previous research has argued that the desire to lower organizational costs was among the main reasons why some companies change their vertical integration strategies (Mpoyi and Bullington, 2004). Evidence can be found in existing literatures that both increasing and decreasing of vertical integration levels can result in lower cost. Two possible reasons can explain why increasing vertical integration level can lower cost. On one hand, if a company can share its existing core competencies with its vertically integrated activities, it will achieve economies of scope, which will in turn reduce unit cost. On the other hand, if market transaction costs are higher, it may be more efficient for companies to integrate and internally perform the activity (Harrigan, 1985; Mpoyi and Bullington, 2004). There are also some literatures claim that a decrease in vertical integration levels can result in a decline in cost, especially when the new information technologies dramatically lower transaction costs. Independent vendors can often achieve economies of scale that may not be achievable inside the manufacturer, and the vendors often pass back some of the savings to the client (Jurison, 1995). If rivalry among independent suppliers is high, competitive pressure will bring down the cost of buying activities from external vendors (D'Aveni and Ravenscraft, 1994). The above argues suggest that changes in vertical integration levels will lead to a decline in cost. This relationship is summarized in the following hypothesis.

H3a. Changes of vertical integration, no matter increase or decrease, have a positive effect on cost performance.

Changes of vertical integration levels and quality performance

Compared to cost, there is less literatures talk about the relationship between vertical integration and quality. Among a few existing literatures, there exist arguments that both increasing and decreasing of vertical integration levels can result in better quality. Researchers that recommend buying from open market argue that this activity tends to promote competition among outside suppliers, thereby ensuring availability of higher-quality goods and service in the future (Kotabe and Murray, 1990). Quality improvements may also be realized by choosing suppliers whose products or services are considered to be among the best in the world (Dess et al., 1995; Quinn, 1992). On the contrary, researchers that recommend increasing vertically integration level argue that direct management result in higher quality since firms have the control of input quality (Singer, et al., 2003; Economides, 1999; D'Aveni and Ravenscraft, 1994). The following hypothesis summarizes the above argues.

H3b. Changes of vertical integration, no matter increase or decrease, have a positive effect on quality performance.

Changes of vertical integration levels and delivery performance

Few literatures address the relationship between vertical integration and delivery performance, but there are some literatures talk about supply uncertainty and vertical integration (e.g. Kouvelis and Milner, 2002). When supply uncertainty is high, firms tends to have higher levels of vertical integration to decrease the uncertainty level. When supply uncertainty is low, firms may turn to rely more on open market. The avoidance of uncertainty can be used as a way to ensure delivery performance. This leads to the next hypothesis.

$\mathrm{H} 3 \mathrm{c}$. Changes of vertical integration, no matter increase or decrease, have a positive effect on delivery performance.

Changes of vertical integration levels and flexibility performance

Flexibility is a multidimensional concept, and it is comprised of several distinct dimensions (Gerwin, 1993; Vokurka et al., 2000). This paper will focus on product mix flexibility, volume flexibility, and new product flexibility. 
Existing literatures have different opinions on the relationships between vertical integration and different kinds of flexibilities. Many scholars argue that in-house production is constrained by the firm's capability and may limit product flexibility (Harrigan, 1985). However, firms using open market can quick response to changes in product and volume requirements (Dess, et al., 1995). This leads to a hypothesis that increase the vertical integration level will decrease product mix flexibility and volume flexibility. Some researchers identify that one of the most serious threats resulting from a reliance on open market is declining innovation of the manufacturers. Relying on open market can lead to a loss of long-run research and development competitiveness (Teece, 1987) because it is often used as a substitute for innovation. As a result, firms that use open market are likely to lose touch with new technological breakthroughs that offer opportunities for product and process innovations.

This leads to a hypothesis that increase the vertical integration level will increase new product flexibility. The hypotheses are summarized as below.

$\mathrm{H} 3 \mathrm{~d}(1)$. Increasing of vertical integration levels results in lower product mix flexibility.

$\mathrm{H} 3 \mathrm{~d}(2)$. Increasing of vertical integration levels results in lower volume flexibility.

$\mathrm{H} 3 \mathrm{~d}(3)$. Increasing of vertical integration levels results in higher new product flexibility.

\section{Research Design}

\subsection{The Sample}

The current study uses a secondary data source to empirically evaluate the hypotheses proposed in the paper. The data source is plant-level data from World-Class Manufacturing (WCM) Round Two database. The WCM database is the result of a two-phased, research endeavor initiated by researchers at the university of Minnesota and Iowa State University in 1989 and expanded to include researchers from Germany, Italy, Japan, and the UK in 1992. The WCM study sought to better understand what the implementation of WCM meant in terms of "best practices" and their impact on plant performance. WCM database is a valuable and comprehensive source of data to conduct plant-level research. More information about WCM database can be seen in Flynn et al., 1997 and Rungtusanatham and Forza, 2004. Round Two database has data of 164 companies from three industries, which are electronics, transportation-related and machinery. Due to some missing data, information from 141 companies is used in the analysis. The deliberate inclusion of more than one industry in the country sub-sample construction was to allow for an improved ability to generalize empirical results. For each country sub-sample, the researchers then obtained insights from known experts, trade journals, and financial information to identify and select plants as having either a world-class or a non-world-class reputation. Details about the German, Italian, Japanese, UK, and USA sub-samples are shown in table 1. Because of missing data of industry types for UK firms, I allocate the 12 firms evenly in each cell. Since the number of firms from UK is only a small proportion of the whole sample, this would not affect the overall view of the data distribution.

$<$ Insert Table 1 Here>

\subsection{Measurement of Variables}

The measures for these variables are constructed after the WCM project data has been collected. The author has selected the perceptual and objective measures that correspond closely to the description of the construct in the proposed framework from the existing WCM project round two data set. Except for changes of vertical integration levels, all items measures are measured on a 1-5 Likert scale.

\section{Business strategy}

Dess and Davis (1984) provide an instrument to operationalize Porter's generic strategic types. The instrument is validated by Kotha and Vadlamani (1995) and has been used frequently in strategy research. For example, Ward and Duray (2000) adapt the instrument to measure the price and differentiation aspects of business strategy, which is called competitive strategy in their research. This paper also adapts Dess and Davis (1984) instrument to measure the two business strategies: cost leader and differentiation. Cost leader strategy is measured by a one-item scale, and the item used is product selling price. Lower score of this item means the company focuses more on cost leader strategy. I reverse the scale for the convenience of explanation, so we would expect a positive relationship between cost leader strategy and changes of vertical integration level. A five-item scale is used to measure differentiation strategy. The items include percent of sales spent on R \& D, percent of sales spent on marketing expenses, product quality, brand image, and product features. The factor loading, correlation and Cronbach's alpha are reported in table 2. As shown in table 2, all five items load on one factor, with an eigenvalue of 2.686 explaining almost $54 \%$ of the variation. Cronbach's alpha is 0.773 . The results of table 2 show that the measurement is acceptable for research. 
$<$ Insert Table 2 Here $>$

Changes of vertical integration level

There are several measures for vertical integration in existing literatures. For example, D'Aveni and Ravenscraft (1994) use the ratio of internal flow of goods to the goods exchanged in the open market as their measure of vertical integration level. Mpoyi (2003) measures vertical integration by using the concept of business segments. He calculates vertical integration level as the ratio of the number of vertically integrated segments over the total number of segments. According to Harrigan (1984), the choice of the appropriate measure depends on the dimension of vertical integration being studied. In her research, Harrigan identified four dimensions of vertical integration: breadth of integrated activities, stages of integrated activities, degree of integration, and form of ownership. This research focuses on the degree of vertical integration, which is defined as the proportion of total input or output a plant purchases from or sells to other business units within the same company. Since this study is only interested in the backward vertical integration, percent of materials coming from inside the company is used as a measure of vertical integration level with suppliers. Increase or decrease of the vertical integration levels is measured as the difference of the percentages during a two-year period. Changes of vertical integration level are the absolute values of the differences.

To better understand the results of the analysis, it seems useful to discuss the descriptive characteristic of vertical integration changes. The types of changes that occurred in companies' vertical integration levels are shown in table 3 . As can be seen in table 3, of the 141 companies in the sample, 88 companies (62\%) did not change their vertical integration levels. 53 companies (38\%) changed their vertical integration levels. Of these companies, 24 increased their levels, and 29 decreased their levels.

$<$ Insert Table 3 Here $>$

Operating performance

Previous research often treats operating performance as with four dimensions: cost, quality, delivery, and flexibility. Accordingly, this study also examines manufacturing performance with these four dimensions. Metrics for these performance dimensions are adapted from previous research (Klassen and Whybark, 1999; Roth and Miller, 1990). Cost is measured as unit cost of manufacturing. Quality is measured as quality of product conformance. Delivery performance (on-time delivery) and fast delivery are used to measure delivery respectively. Three dimensions are used to measure flexibility separately, which are flexibility to change product mix, flexibility to change volume, and speed of new product introduction. The items used are summarized in Appendix A.

\section{Control variables}

Industries and plant size are used in the model as control variables. Two dummy variables are used to represent three industries. Dummy variable one is coded as 1 for Machinery, 0 for Electronic, and -1 for Transportation-related industry. Dummy variable two is coded as 1 for Electronic, 0 for Machinery, and -1 for Transportation-related industry. The log of the number of employees (include hourly personnel and salaried personnel) is used to measure size (Kimberly, 1976).

\subsection{Model Evaluation}

This study uses hierarchical regression analysis to investigate the relationships hypothesized in section 3 . Hierarchical regression analysis is a good way to examine the relationships among variables after taking into account variance attributable to other variables (Rosenzweig, et al., 2003; Pedhazur and Schmelkin, 1991). To test the first and second hypotheses, the control variable industries and then business strategies are regressed on the changes of vertical integration. Log transformation of changes of vertical integration is used here to meet the normality assumption of the regression model. In testing the third hypotheses that employ the operating performance measures as the dependent variables, industries and size are used as control variables and changes (or increase) of vertical integration levels is independent variable.

\section{Results and Discussion}

\subsection{Business Strategies and Changes of Vertical Integration Level}

Industries are used as control variables, since several studies of vertical integration have conceptually and empirically supported the importance of industries as a determinant of vertical integration strategies (e.g. Balakrishnan and Wernerflet, 1986; Harrigan, 1985). According to Mpoyi (2003)'s research, the levels of vertical integration are significantly influenced by type of industry. So vertical integration levels are industry-specific. Since companies in a particular industry are facing the same or similar conditions, to be competitive, these companies 
should respond to those conditions by adopting the same or similar vertical integration levels. As competitive settings of a particular industry change, the need for vertical integration will also change. So we would expect that changes of vertical integration levels are also industry specific. The regression results are shown in table 4 .

$<$ Insert Table 4 Here $>$

As posited in $\mathrm{H} 1$, the empirical results demonstrate that high focus on cost leader strategy leads to higher change of vertical integration level after controlling for industries. The positive relationship between cost leader strategy and changes of vertical integration level is statistically significant $(\beta=0.413$, p-value $<0.01)$. The results support the argument made in section 3 that firms change their vertical integration level mainly for cost consideration. Although the regression coefficient of differentiation strategy is negative, which is the same direction as we expected, the relationship between differentiation strategy and changes of vertical integration level is not statistically significant ( $p$-value $>0.1$ ). This result only partially supports H2. Compared to cost leaders, differentiators pay less attention to the changes of vertically integration level since existing research fails to show sufficient benefits of vertical integration other than lowering cost.

The dummy variable industry type is a significant predictor of changes of vertical integration ( $\mathrm{p}$-value $<0.01$ ). Previous research has proven that vertical integration level is industry specific (Balakrishnan and Wernerflet, 1986; Harrigan, 1985; Mpoyi, 2003). This research shows that change of vertical integration levels is also contingent on industries. This result is consistent with the argument that firms in the same industry face similar competitive settings and similar changes of the settings, thus response to the changing environment in a similar way.

\subsection{Changes of Vertical Integration Levels and Operating Performance}

To investigate the relationships between changes of vertical integration level and different performance measures, I control for two contextual factors: industry and plant size. Both of them have been used in recent studies on performance (e.g. Mpoyi and Bullington, 2004; Shah and Ward, 2003; Rosenzweig et al., 2003). Examination of models 1 and models 2 in table 5 and table 6 enables us to determine if the H3 hypotheses set get supported or not. Table 5 and table 6 show some surprising results.

$<$ Insert Table 5 Here>

$<$ Insert Table 6 Here $>$

First, the study fails to find a significant relationship between changes of vertical integration levels and cost, although the regression coefficient is positive as I expected $(\beta=0.115$, p-value $>0.1)$. This is surprising because according to existing literature, seeking for low cost is the main reason that firms changing their vertical integration level. There are some possible explanations for this result. One possible explanation is that using a one-item scale to measure vertical integration level may not capture the full meaning of the construct since vertical integration is a multidimensional construct (Harrigan, 1985). Another possible explanation is that firms do not get what they want from changing vertical integration levels. Most of the arguments about reducing cost through increasing or decreasing vertical integration are based on theoretical justification and anecdotal evidence. Empirical test is a missing part of the topic.

Second, the study finds significant relationships between changes of vertical integration level and quality $(\beta=-0.185$, p-value $<0.05)$, on-time delivery $(\beta=-0.255$, p-value $<0.01)$, and fast delivery $(\beta=-0.334, p$-value $<0.01)$, but the relationships are all negative. Changes of vertical integration level lower quality and delivery performance, which is different from what the existing literatures support. One explanation of the result is that firms need relatively long time to establish quality and delivery performance. Changes of vertical integration may negatively influence quality and delivery performance in short run, but in the long run, the relationship may be different. Since the changes of vertical integration in this study all happened in a two-year period, I would be cautious to draw any certain conclusions about this.

Since existing literature only support the relationship between flexibility and one direction change of vertical integration, independent variable in table 5 is the increase of vertical integration instead of changes of vertical integration. As shown in table 5, $\mathrm{H} 3 \mathrm{~d}(1)$ is supported $(\beta=-0.225$, p-value $<0.05)$, which means the increase of vertical integration level results in lower product mix flexibility. The result is consistent with the arguments researchers have made in existing literature. The regression coefficient between the increase of vertical integration and volume flexibility is negative, but it is not statistically significant $(\beta=-0.121, p$-value $>0.1)$. One surprising result is the negative relationship $(\beta=-0.181$, $\mathrm{p}$-value $<0.05)$ between the increase of vertical integration level and new product flexibility, which is measured as the speed of new product introduction. This finding is surprising because many scholars have claimed that lower vertical integration level will impair firms' innovation competitiveness. One 
possible explanation is that there may exist difference between short term and long-term results. In long run, outsourcing or vertical disintegration may lead firms to a loss of research and development competitiveness (Teece, 1987; Gilley and Rasheed, 2000). But in short term, companies using open market may enjoy higher speed of new product introduction since they have the access to technical expertise and specialists in the open market, which is a larger pool of creative talent.

\section{Conclusions}

Pursuing high levels of vertical integration has been a long time feature of the manufacturing sector (Harrigan, 1984; Steingraber, 1990). The benefits of vertical integration are theoretically justified by many researchers based on transaction cost theory (e.g. D'Avenei and Ravenscraft, 1994). However, several researchers have mentioned recently a growing trend toward vertical disintegration or outsourcing (e.g. D'Aveni and Ravenscraft, 1994; Quinn, 1992; Gilley and Rasheed, 2000). After outsourcing has dominated for about two decades, it has been noticed that some big companies are taking a page from the past. Instead of outsourcing more functions, they are trying to gain a higher level of vertical integration. Based on these two inconsistent views and conflicting phenomena, a few researchers propose that firms should change their vertical integration level according to the changes of competitive environment to lower the cost (e.g. Mpoyi and Bullington, 2004). Since lowering cost is the main reason that firms change their vertical integration level, this paper proposes that firms with different business strategic objectives are not equal likely to change their vertical integration level. The empirical results show that cost leaders tend to change their vertical integration level more than differentiators. This paper also empirically test the relationship between changes of vertical integration level and operating performance. The results show that firms should be cautious about changing their vertical integration level. There may exist significant performance tradeoffs when changing vertical integration level to get lower cost.

One limitation of the research is the use of secondary data source. Although secondary data sources have been fruitfully used in empirical research, they also present some limitations. In particular, the measures for the variables used in the study are constructed after the WCM project data has been collected. One-item scale for the measurement of vertical integration level may not exactly capture the multidimensional construct. So the research results need to be explained with caution. Another limitation is that the data only takes into account two-year changes of vertically integration level. Some effects may appear in the long run that cannot be captured in this study.

Further research on this topic can use a comprehensive measure for vertical integration and track the changes of vertical integration level and performance in a longer period of time. This study uses perceptual measurements for operating performance. In future research, objective performance measurement scales can be used to test the hypotheses proposed in this paper. We may get more insight on the relationship between changes of vertical integration level and performance. Further research can also control more contextual factors to investigate the relationship between changes of vertical integration and performance, such as environmental uncertainty, competition intensity. This will provide more insights on this phenomenon.

\section{References}

Anderson, E. (1985). The salesperson as outside agent or employee: A transaction cost analysis. Marketing Science, 4, 234-254. http://dx.doi.org/10.1287/mksc.4.3.234

Balakrishenan, S., \& Wernerfelt, B. (1986). Technical change, competition and vertical integration. Strategic management Journal, 7, 347-359. http://dx.doi.org/10.1002/smj.4250070405

Barreyre, P. Y. (1988). The concept of "impartation" policies: A different approach to vertical integration strategies. Strategic management Journal, 9, 507-520. http://dx.doi.org/10.1002/smj.4250090509

Brickley, J. A., Linck, J. S., \& Smith, C. W. (2012). Vertical integration to avoid contracting with potential competitors: Evidence from bankers' banks. Journal of Financial Economics, 105(1), 113-130. http://dx.doi.org/10.1016/j.jfineco.2011.09.001

Chandler, A. D. (1990). Scale and scope. Cambridge, MA: The Belknap Press.

Coase, R. H. (1937). The nature of the firm. Economica, 4, 386-405. http://dx.doi.org/10.1111/j.1468-0335.1937.tb00002.x

D'Aveni, R. A., \& Ilinitch, A.V. (1992). Complex patterns of vertical integration in the forest products industry: systematic and bankruptcy risk. Academy of Management Journal, 35, 596-625. http://dx.doi.org/10.2307/256488 
D'Aveni, R. A., \& Ravenscraft, D.J. (1994). Economies of integration versus bureaucracy costs: Does vertical integration improve performance? Academy of Management Journal, 37, 1167-1206. http://dx.doi.org/10.2307/256670

Davis, R., \& Duhaime, I.M. (1992). Diversification, vertical integration, and industry analysis: New Perspectives and measurement. Strategic management Journal, 13, 511-524. http://dx.doi.org/10.1002/smj.4250130704

Dess, G. G., \& Davis, P.S. (1984). Porter's (1980) generic strategies as determinants of strategic group membership and organizational performance. Academy of Management Journal, 27(3), 467-488. http://dx.doi.org/10.2307/256040

Dess, G. G., Rasheed, A., McLaughlin, K., \& Priem, R. (1995). The new corporate architecture. Academy of Management Executive, 9(3), 7-20.

Economides, N. (1999). Quality choice and vertical integration. International Journal of Industrial Organization, 17, 903. http://dx.doi.org/10.1016/S0167-7187(97)00063-5

Fernandes, A. P., \& Tang, H. (2012). Determinants of vertical integration in export processing: Theory and evidence from China. Journal of Development Economics, 99(2), 396-414. http://dx.doi.org/10.1016/j.jdeveco.2012.05.004

Flynn, B. B., \& Schroeder, R. G. (1997). World-class manufacturing project: Overview and selected results. International Journal of Operations \& Production Management, 17, 671, Emerald. http://dx.doi.org/10.1108/01443579710175592

Frank, S. D., \& Henderson, D. R. (1992). Transactions costs as determinants of vertical coordination in the U.S. food industries. American Journal of Agricultural Economics, 74, 941, Blackwell Publishing Limited. http://dx.doi.org/10.2307/1243192

Gerwin, D. (1993). Manufacturing flexibility: a strategic perspective. Management Science, 39(4), 395-410. http://dx.doi.org/10.1287/mnsc.39.4.395

Gilley, K. M., \& Rasheed, A. (2000). Making more by doing less: An analysis of outsourcing and its effects on firm performance. Journal of Management, 26(4), 763-790.

Grossman, G. M., \& Helpman, E. (2002). Integration Versus Outsourcing in Industry Equilibrium. Quarterly Journal of Economics, 117, 85-120, MIT Press. http://dx.doi.org/10.1162/003355302753399454

Gurbaxani, V., \& Whang, S. (1996). The impact of information systems on organizations and markets. Communications of ACM, 34(1), 59-73. http://dx.doi.org/10.1145/99977.99990

Harrigan, K. R. (1983). A Framework For Looking at Vertical Integration. Journal of Business Strategy, 3, 30, Emerald. http://dx.doi.org/10.1108/eb038975

Harrigan, K. R. (1984). Formulating vertical integration strategies. Academy of Management Review, 9, 638-652.

Harrigan, K. R. (1985a). Exit barriers and vertical integration. Academy of Management Review, 28, 686-697. http://dx.doi.org/10.2307/256124

Harrigan, K. R. (1985b). Strategies for intrafirm transfers and outside sourcing. Academy of Management Journal, 28, 914-925. http://dx.doi.org/10.2307/256244

John, G., \& Weitz, B.A. (1988). Forward integration into distribution: An empirical test of transaction cost analysis. Journal of Law, Economics and Organization, 4, 121-139.

Jones, G. R., \& Hill, C.W.L. (1988). Transaction cost analysis of strategy-structure choice. Strategic management Jouranl, 9, 159-172. http://dx.doi.org/10.1002/smj.4250090206

Jurison, J. (1995). The role of risk and return in information technology outsourcing decisions. Journal of Information Technology, 10, 239-247. http://dx.doi.org/10.1057/jit.1995.27

Katie, M. (2003). Say Goodbye to Vertical Integration. Direct, 15, 85, Primedia Business Magazines \& Media Inc.

Kimberly, J. R. (1976). Organizational size and the structuralist perspective: A review, critique, and proposal. Administrative Science Quarterly, 21, 571-597. http://dx.doi.org/10.2307/2391717

Klassen, R. D., \& Whybark, D.C. (1999). The impact of environmental technologies on manufacturing performance. Academy of Management Journal, 42(6), 599-615. http://dx.doi.org/10.2307/256982 
Kotabe, M., \& Murray, J. (1990). Linking product and process innovations and modes of international sourcing in global competition: A case of foreign multinational firms. Journal of International Business Studies, 3, 383-408. http://dx.doi.org/10.1057/palgrave.jibs.8490339

Kotha, S., \& Vadlamani, B.L. (1995). Assessing generic strategies: an empirical investigation of two competing typologies in discrete manufacturing industries. Strategic management Journal, 16, 75-83. http://dx.doi.org/10.1002/smj.4250160108

Kouvelis, P., \& Milner, J. M. (2002). Supply chain capacity and outsourcing decisions: the dynamic interplay of demand and supply uncertainty. IIE Transactions, 34, 717, Taylor \& Francis Ltd. http://dx.doi.org/10.1080/07408170208928907

Lei, D., \& Hitt, M. (1995). Strategic restructuring and outsourcing: The effect of mergers and acquisitions and LBOs on building firm skills and capabilities. Journal of Management, 21(5), 835-859. http://dx.doi.org/10.1177/014920639502100502

Levy, D. T. (1985). The Transactions Cost Approach to Vertical Integration: An Empirical Examination. Review of Economics \& Statistics, 67, 438, MIT Press. http://dx.doi.org/10.2307/1925972

Lieberman, M. B. (1991). Determinants of vertical integration: An empirical test. Journal of Industrial Economics, 39, 451-466. http://dx.doi.org/10.2307/2098455

Mahoney, J. T. (1992). The choice of organizational form: Vertical ownership versus other methods of vertical integration. Strategic management Journal, 13, 559-584. http://dx.doi.org/10.1002/smj.4250130802

Masten, S. E., Meehan, J.W., \& Snyder, E.A. (1989). Vertical integration in the U.S. auto industry: A note on the influence of transaction specific assets. Journal of Economic Behavior and Organization, 12, 265-273. http://dx.doi.org/10.1016/0167-2681(89)90059-0

McAfee, R. P. (1999). The Effects of Vertical Integration on Competing Input Suppliers, Economic Review (Federal Reserve Bank of Cleveland), 35, 2, Federal Reserve Bank of Cleveland.

Monteverde, K., \& Teece, D.J. (1982). Supplier switching costs and vertical integration in the automobile industry. Bell Journal of Economics, 13, 206-213. http://dx.doi.org/10.2307/3003441

Mpoyi, R. T. (2003). Vertical Integration: Strategic Characteristics and Competitive Implications. Competitiveness Review, 13, 44, American Society for Competitiveness. http://dx.doi.org/10.1108/eb046451

Mpoyi, R. T., \& Bulington, K. E. (2004). Performance Implications of Changing Vertical Integration Strategies. American Business Review, 22, 93-101, University of New Haven School of Business.

Pedhazur, E., \& Schmelkin, L. (1991). Measurement, design and analysis: An integrated approach. Hillsdale, NJ: Lawrence Erlbaum Associates.

Quinn, J. B., Doorley, T.L., \& Paquette, P.C. (1990). Technology in services: Rethinking strategic focus. Sloan Management Review, 31(2), 79-87.

Quinn, J. B. (1992). Intelligent enterprise: A knowledge and service based paradigm for industry. New York: Free Press.

Rindfleisch, A., \& Heide, J.B. (1997). Transaction cost analysis: Past, present, and future applications. Journal of Marketing, 61, 30-54. http://dx.doi.org/10.2307/1252085

Riordan, M. H., \& Sappington, D.E.M. (1987). Information, incentives and organizational mode. Quarterly Journal of Economics, 102, 243-263. http://dx.doi.org/10.2307/1885062

Robins, J. A. (1993). Organization as strategy: Restructuring production in the film industry. Strategic management Journal, 14, 103-118. http://dx.doi.org/10.1002/smj.4250140909

Rosenzweig, E. D., Roth, A.V., \& Dean Jr, J.W. (2003). The influence of an integration strategy on competitive capabilities and business performance: An exploratory study of consumer products manufacturers. Journal of Operations Management, 21, 437-456. http://dx.doi.org/10.1016/S0272-6963(03)00037-8

Roth, A. V., \& Miller, J.G. (1990). Manufacturing strategy, manufacturing strength, managerial success and economic outcomes. In Manufacturing strategy. Boston, MA: Kluwer Academic. http://dx.doi.org/10.1007/978-94-009-2189-4_11 
Rungtusanatham, M., \& Forza, C. (2004). Coordinating product design, process design, and supply chain design decisions Part A: Topic motivation, performance implications, and article review process. Journal of Operations Management, In Press.

Shah, R., \& Ward, P.T. (2003). Lean manufacturing: context, practice bundles, and performance. Journal of Operations Management, 21, 129-149. http://dx.doi.org/10.1016/S0272-6963(02)00108-0

Singer, M., Donoso, P., \& Traverso, P. (2003). Quality strategies in supply chain alliances of disposable items. Omega (Oxford), 31, 499. http://dx.doi.org/10.1016/j.omega.2003.08.006

Steenkamp, J., \& Geyskens, I. (2012). Transaction cost economics and the roles of national culture: a test of hypotheses based on Inglehart and Hofstede. Journal of the Academy of Marketing Science, 40(2), 252-270. http://dx.doi.org/10.1007/s11747-011-0266-1

Steingraber, F. (1990). Managing in the 1990s. Business Horizons, 33, 50-61. http://dx.doi.org/10.1016/0007-6813(90)90072-J

Stuckey, J., \& White, D. (1993). When and when not to vertical integrate. Sloan Management Review, 34, 71-83.

Teece, D. (1987). Capturing value from technological innovation: Integration, strategic partnering, and licensing decisions. In B. Guile and H. Brooks (Eds), Technology and global industry (pp. 65-95). Washington: National Academy Press.

Vokurka, R. J., \& O'Leary-Kelly, S.W. (2000). A review of empirical research on manufacturing flexibility. Journal of Operations Management, 18, 485-501. http://dx.doi.org/10.1016/S0272-6963(00)00031-0

Walker, G., \& Weber, D. (1984). A transaction cost approach in make-or-buy decisions. Administrative Science Quarterly, 29, 373-391. http://dx.doi.org/10.2307/2393030

Ward, P. T., \& Duray, R. (2000). Manufacturing strategy in context: environment, competitive strategy and manufacturing strategy. Journal of Operations Management, 18, 123-138. http://dx.doi.org/10.1016/S0272-6963(99)00021-2

Williamson, O. E. (1975). Markets and hierarchies: Analysis and antitrust implication. New York: Free Press.

Williamson, O. E. (1979). Transaction-cost economics: the governance of contractual relations. Journal of Law, and Economics, 22, 233-262. http://dx.doi.org/10.1086/466942

Williamson, O. E. (1981). The economics of organization: The transaction cost approach. American Journal of Sociology, 87, 549-557. http://dx.doi.org/10.1086/227496

Williamson, O. E. (1985). The Economic Institutions of Capitalism: Firms, Markets, Relational Contracting. New York: The Free Press.

Table 1. Distribution of the sample

\begin{tabular}{|c|c|c|c|c|c|c|c|}
\hline \multirow[t]{3}{*}{ country } & \multicolumn{6}{|c|}{ Industry } & \multirow{3}{*}{$\begin{array}{l}\mathbf{N} \text { (by } \\
\text { country) }\end{array}$} \\
\hline & \multicolumn{2}{|c|}{ Electronics } & \multicolumn{2}{|c|}{ Machinery } & \multicolumn{2}{|c|}{ Transportation-related } & \\
\hline & WCM & Non-WCM & WCM & Non-WCM & WCM & $\begin{array}{l}\text { Non- } \\
\text { WCM }\end{array}$ & \\
\hline Germany & 2 & 4 & 5 & 6 & 5 & 8 & 30 \\
\hline Italy & 8 & 3 & 4 & 7 & 5 & 4 & 31 \\
\hline Japan & 10 & 5 & 11 & 2 & 7 & 7 & 42 \\
\hline UK & 2 & 2 & 2 & 2 & 2 & 2 & 12 \\
\hline USA & 4 & 5 & 5 & 4 & 4 & 4 & 26 \\
\hline $\begin{array}{l}\text { N (WCM vs. } \\
\text { non-WCM by } \\
\text { industry) }\end{array}$ & 26 & 19 & 27 & 21 & 23 & 25 & \\
\hline $\mathrm{N}$ (by industry) & & 45 & & 48 & & 48 & $\mathrm{~N}=141$ \\
\hline
\end{tabular}


Table 2. Differentiation strategy: factor loading and Spearman correlation

\begin{tabular}{|c|c|c|c|c|c|c|}
\hline & $\begin{array}{r}\text { Factor } \\
\text { loadings }\end{array}$ & Item 1 & Item 2 & Item 3 & Item 4 & Item 5 \\
\hline Percent of sales spent on R \& D & .717 & ----- & & & & \\
\hline $\begin{array}{l}\text { Percent of sales spent on } \\
\text { marketing expenses }\end{array}$ & .598 & .458 & ----- & & & \\
\hline Product quality & .765 & .379 & .229 & ----- & & \\
\hline Brand image & .783 & .412 & .337 & .549 & ----- & \\
\hline Product features & .784 & .412 & .306 & .575 & .515 & ----- \\
\hline \multicolumn{7}{|l|}{ Eigenvalue: 2.686} \\
\hline \multicolumn{7}{|c|}{ Percent of variance explained: 53.72} \\
\hline Cronbach alpha: 0.773 & & & & & & \\
\hline
\end{tabular}

* Extraction method: Principal Component Analysis,

* Rotation method: Varimax with Kaiser Normalization

Table 3. Distribution of companies with different vertical integration level changes

Keep same level of vertical integration

Change the level of vertical integration Increase vertical integration level Decrease vertical integration level

\section{Number of companies} 88

53

24

29
Percentage (\%)

62.4

37.6

17

20.6

Total

141

100

Table 4. Influence of business strategies on changes of vertical integration level

\section{Standardized $\beta$ coefficient}

Dependant variable: change of vertical integration level

(log transformation)

Industry type (M)

Dummy 1

Industry type (E)

Dummy 2

Cost leader

Differentiation

R-Square

Adjusted R-Square

Change in R-Square

P-value of F statistic

P-value of overall model
Model with only control variables Model with all independent variables

$\begin{array}{ll}-0.241 & -0.171 \\ & \\ 0.479^{* * *} & 0.423^{* * *} \\ & 0.413^{* * *} \\ 0.183 & -0.015 \\ 0.146 & 0.356 \\ - & 0.296 \\ - & 0.173 \\ 0.011 & 0.001 \\ & 0.001\end{array}$

- $\quad * \mathrm{P}<0.1$

- $\quad * * \mathrm{P}<0.05$

- $\quad * * * \mathrm{P}<0.01$ 
Table 5. Influence of changes of vertical integration level on cost, quality and delivery

\begin{tabular}{|c|c|c|c|c|c|c|c|c|}
\hline & \multicolumn{2}{|c|}{$\begin{array}{l}\text { Dependent } \\
\text { variable } \\
\end{array}$} & \multicolumn{2}{|c|}{$\begin{array}{l}\text { Dependent variable } \\
\text { Quality }\end{array}$} & \multicolumn{2}{|c|}{$\begin{array}{l}\text { Dependent variable } \\
\text { On-time delivery }\end{array}$} & \multicolumn{2}{|c|}{$\begin{array}{l}\text { Dependent variable } \\
\text { Fast delivery }\end{array}$} \\
\hline & Model1 & Model2 & Model1 & Model2 & Model1 & Model2 & Model1 & Model2 \\
\hline $\begin{array}{l}\text { Industry } \\
\text { type (M) }\end{array}$ & -0.146 & -0.134 & 0.039 & 0.017 & -0.084 & -0.114 & -0.158 & $-0.198 * *$ \\
\hline $\begin{array}{l}\text { Dummy } 1 \\
\text { Industry }\end{array}$ & & & & & & & & \\
\hline $\begin{array}{l}\text { type }(\mathrm{E}) \\
\text { Dummy } 2\end{array}$ & 0.096 & 0.072 & -0.071 & -0.034 & 0.013 & 0.065 & -0.125 & -0.058 \\
\hline $\begin{array}{l}\text { Plant size } \\
\text { Changes }\end{array}$ & $0.687^{*}$ & $0.172 *$ & 0.079 & 0.052 & 0.132 & 0.096 & 0.088 & 0.04 \\
\hline $\begin{array}{l}\text { of vertical } \\
\text { integration } \\
\text { level }\end{array}$ & & 0.115 & & $-0.185^{* *}$ & & $-0.255^{* * *}$ & & $-0.334 * * *$ \\
\hline $\begin{array}{l}\text { R-Square } \\
\text { Adjusted }\end{array}$ & 0.047 & 0.06 & 0.011 & 0.043 & 0.029 & 0.091 & 0.08 & 0.186 \\
\hline $\begin{array}{l}\text { R-Square } \\
\text { Change in }\end{array}$ & 0.024 & 0.029 & 0 & 0.012 & 0.005 & 0.061 & & \\
\hline $\begin{array}{l}\text { R-Square } \\
\text { P-value of }\end{array}$ & & 0.013 & & 0.032 & & 0.062 & & 0.106 \\
\hline $\begin{array}{l}\text { F statistic } \\
\text { P-value of }\end{array}$ & & 0.206 & & 0.043 & & 0.005 & & 0.000 \\
\hline $\begin{array}{l}\text { overall } \\
\text { model }\end{array}$ & 0.112 & 0.108 & 0.718 & 0.242 & 0.301 & 0.019 & 0.016 & 0.000 \\
\hline
\end{tabular}

Table 6. Influence of changes of vertically integration level on flexibility

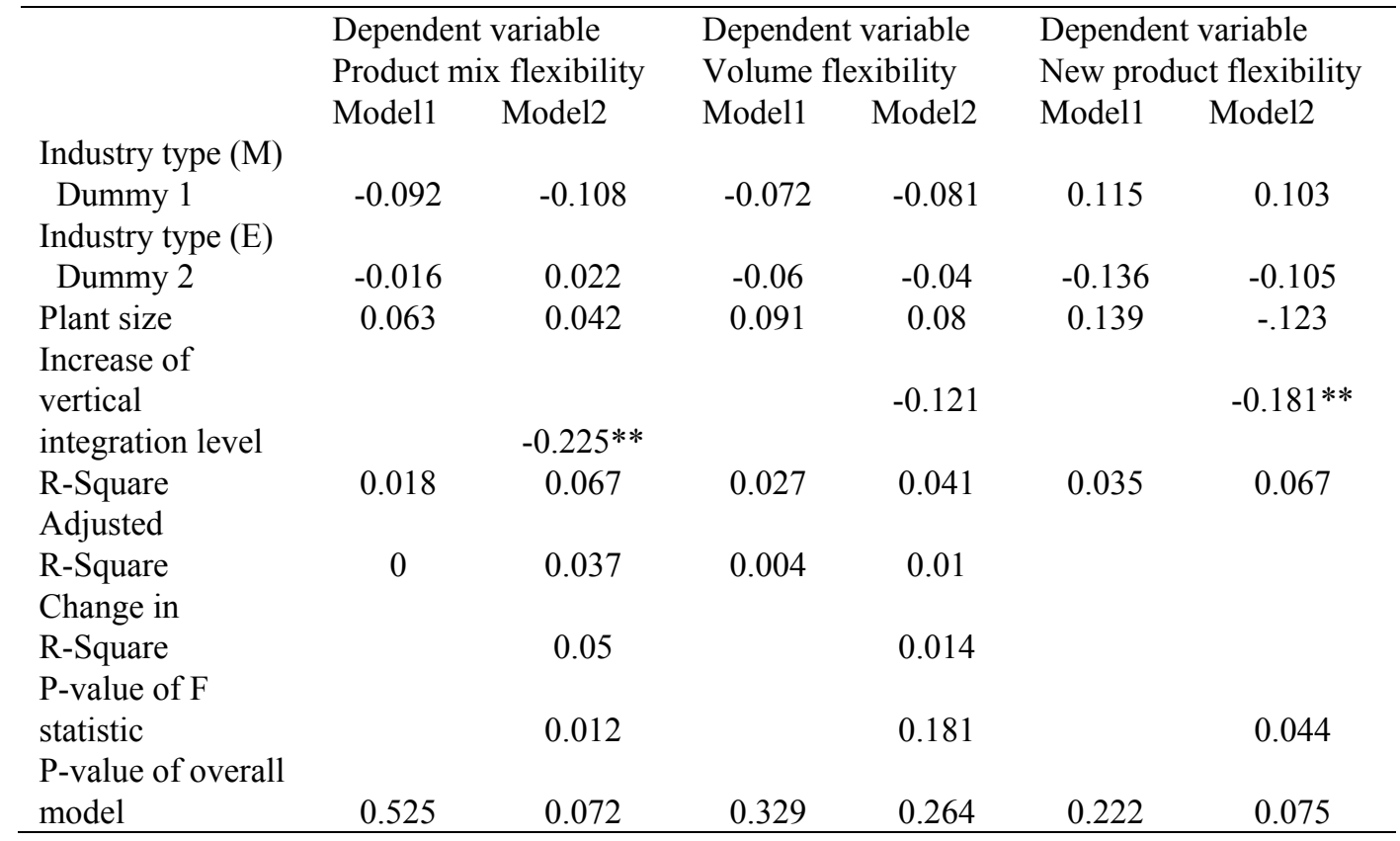

- $\quad * \mathrm{P}<0.1$

- $\quad * * \mathrm{P}<0.05$

- $\quad * * * \mathrm{P}<0.01$ 


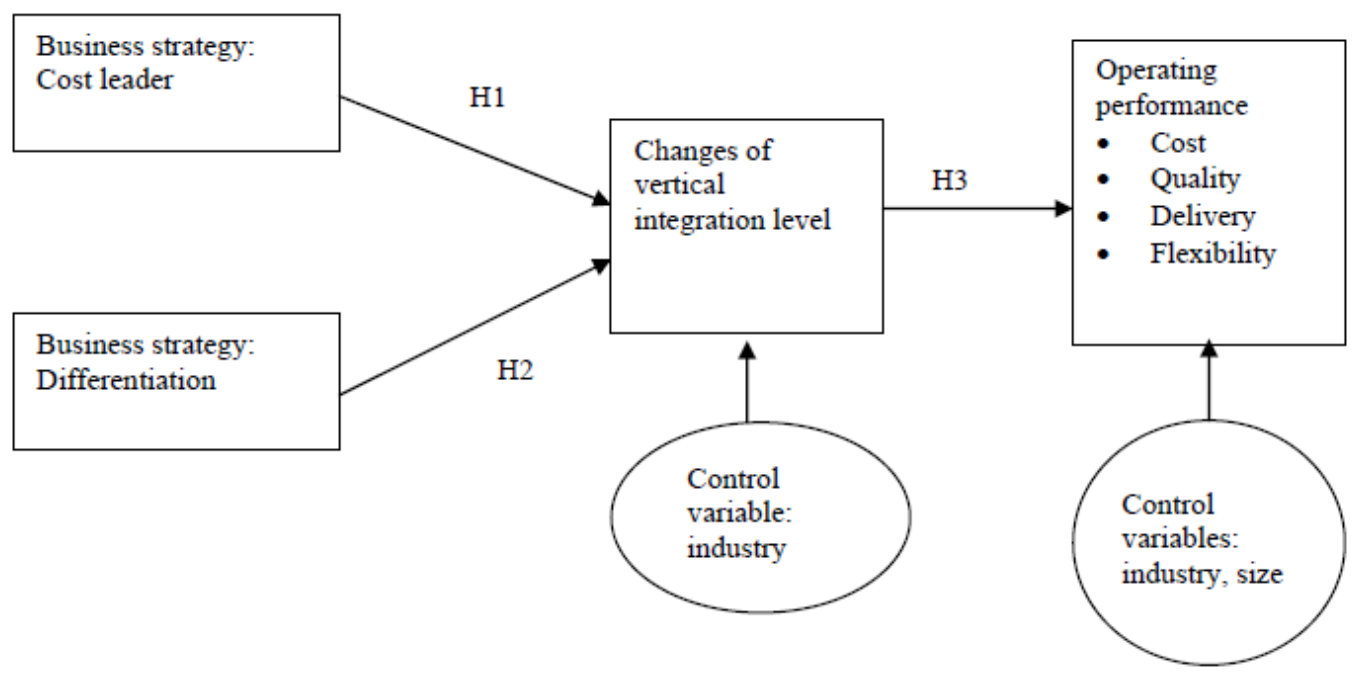

Figure 1. Proposed framework

Appendix A. Items used for developing scales

Business strategy:

how the products produced at this plant compare to their competition.

Price $1=$ significantly lower, 2 = lower, $3=$ about the same, $4=$ higher, $5=$ significantly higher.

Differentiation

Product selling price.

Percent of sales spent on R \& D.

Percent of sales spent on marketing expenses.

Product quality.

Brand image.

Product features.

Operating performance:

how your plant compares to its competition in your industry, on a global basis. $5=$ Superior or better than average, $4=$ Better than average, $3=$ Average or equal to the competition, 2 = Below average, $1=$ Poor or low end of the industry

Cost:

Quality:

Unit cost of manufacturing

Delivery:

Quality of product conformance

Delivery performance (on-time delivery)

Flexibility:

Fast delivery

Flexibility to change product mix

Flexibility to change volume

Speed of new product introduction. 